\title{
ANALYSIS OF THE EFFECT OF OPERATIONAL EFFICIENCY, THIRD-PARTY FUNDS AND NON PERFORMING FINANCE ON PROFITABILITY IN SHARIA BANKING IN INDONESIA
}

\author{
Putri Renalita Sutra Tanjung \\ Universitas Mercu Buana, \\ Jakarta, \\ Indonesia
}

DOI: https://doi.org/10.36713/epra3818

\begin{abstract}
This research aims to know the influence of Operational Efficiency, Third-Party Fund, and Non-Performing Finance to Return on Assets (ROA). The Object for this research is Islamic Banks listed in the Financial Services Authority and Bank Indonesia in the period 2012 to 2016. This research was done to 11 Islamic banks by using a quantitativedescriptive approach. Thus, the data analysis which is used is statistical analysis in the form of the double linear regression test

The result of this research shows that either simultaneously or partially, the Operational Efficiency variable, ThirdParty Fund, and Non-Performing Finance influence to Return On Assets in Islamic Banks. It has been proven from the result of $(f)$ simulant test and the result of $(t)$ partial shows two independent variables did not support the hypothesis. The result of Third-Party Fund, and Non-Performing Finance does not affect Return On Assets (ROA), while Variable Operational Efficiency influences to Return On Assets (ROA) in Islamic Banks.
\end{abstract}

KEYWORDS: Operational Efficiency, Third-Party Fund, Non-Performing Finance, Return On Assets, Sharia

\section{PRELIMINARY}

The performance of Islamic banking has a big role in the development of the economy in Indonesia. When the economic crisis since 1997, the financing system based on Islamic principles can survive and have better performance than conventional banks.

Bank financial institutions have an important role in the economy and national development considering its function as an intermediary institution, payment transaction organizer, and monetary policy transmission tool. According to Law No. 7 of 1992 concerning banking as amended by Law RI No. 10 of 1998 concerning banking, what is meant by banks is a business entity that collects funds from the public in the form of deposits and distributes them to the community in the form of credit and other forms in order to increase the living standards of many people.

Islamic banks are banks whose activities refer to Islamic law, and in their activities do not charge interest or pay interest to customers. Rewards received by Islamic banks as well as those paid to customers depend on the contract and agreement between the customer and the bank. Agreements (contracts) that exist in Islamic banking must be subject to the terms and conditions of the contract as regulated in Islamic Law (Ismail, 2010).

The Financial Services Authority (OJK) states that currently, total sharia banking customers reach around 15 million people. Meanwhile, conventional banking customers total to around 80 million people. Compared to conventional banks, total sharia bank customers only reached $18.75 \%$ (beritasatu.com). 
According to sharia banking statistics in 2011 published by Bank Indonesia, nationally the volume of sharia banking business consisting of total assets and total third party funds channeled by Islamic banks increased. Total assets in 2011 which were only Rp141 Billion increased to Rp 190 Billion, total third party funds in 2011 amounted to $\mathrm{Rp} 118$ Billion to Rp 141 Billion.

Several factors might affect the level of profitability in Islamic banking, namely third party funds (DPK), non-performing finance (NPF) and operational efficiency. E dispense operation is a tool to measure the efficiency and ability of banks to perform all operations. Operational efficiency is very important for banks to increase the level of profit to be achieved. One of the ratios commonly used to measure the level of bank efficiency is the Ratio of Operating Costs to Operating Income (Buchori, 2015).

Table 1 . Development of ROA in Islamic Commercial Banks in Indonesia for the period 20122016

\begin{tabular}{|c|c|c|c|c|c|}
\hline Period & BSM & BRIS & BVS & BJBS & BMSI \\
\hline $\mathbf{2 0 1 2}$ & $2.25 \%$ & $1.19 \%$ & $1.43 \%$ & $-0.59 \%$ & $2.88 \%$ \\
\hline $\mathbf{2 0 1 3}$ & $1.53 \%$ & $1.15 \%$ & $0.50 \%$ & $0.91 \%$ & $2.87 \%$ \\
\hline $\mathbf{2 0 1 4}$ & $-0.04 \%$ & $0.08 \%$ & $-1.87 \%$ & $0.69 \%$ & $3.61 \%$ \\
\hline $\mathbf{2 0 1 5}$ & $0.56 \%$ & $0.76 \%$ & $-2.36 \%$ & $0.25 \%$ & $-20.13 \%$ \\
\hline $\mathbf{2 0 1 6}$ & $0.59 \%$ & $0.95 \%$ & $-2.19 \%$ & $-8.09 \%$ & $-9.51 \%$ \\
\hline
\end{tabular}

Source: Sharia Commercial Banks financial statements

The decline in ROA occurred in 5 Sharia Commercial Banks, namely BSM, BRIS, BVS, BJBS, BMSI. In BSM, the annual decrease in 2012 was $2.25 \%$ to $0.59 \%$ in 2016 . Then in BRIS, the decrease in 2012 was $1.19 \%$ to $0.95 \%$ in 2016 . In BVS, the decrease in 2014 was $-1,87 \%$ to $-2.19 \%$ in 2016. In BJBS it decreased in 2013 by $0.91 \%$ to $8.09 \%$ in 2016 . And in BMSI it decreased by $2.88 \%$ to $-9.51 \%$ in 2016 .
From this phenomenon, it can be concluded that not every empirical event is by existing theories. This is reinforced by the Research Gap in previous studies. The various studies above show the different effects of banks on Return On Assets (ROA). OPERATIONAL EFFICIENCY is a comparison between total operating costs and total operating income.

\section{Figure 1. Comparison of Conventional Banks and Sharia Banks OPERATIONAL EFFICIENCY}

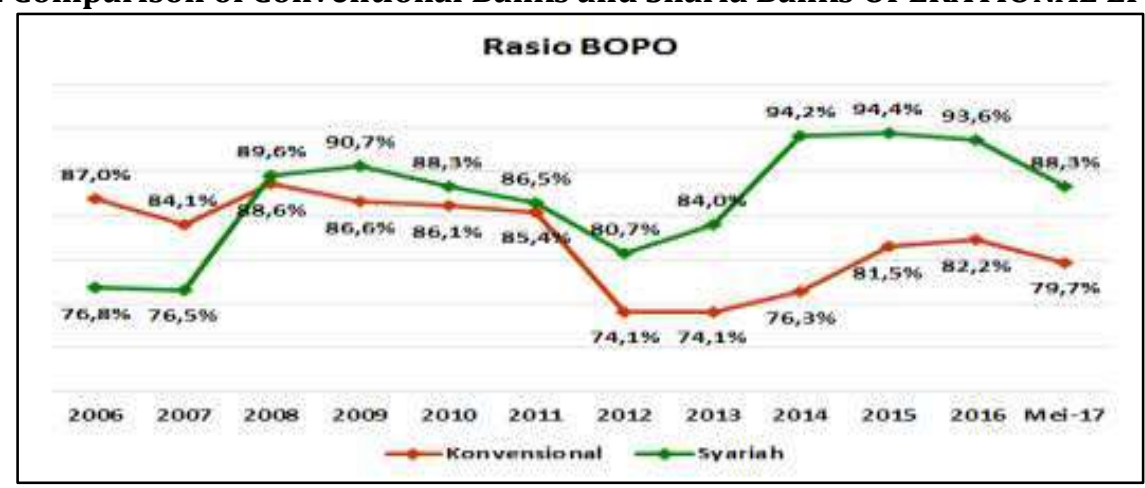

Source: Deposit Insurance Agency

From Figure 1. above, it can be seen that the Sharia banking OPERATIONAL EFFICIENCY ratio has declined since 2012, this is a warning for management to be more selective in issuing operational costs. If management can reduce the expenditure of operational costs, it is expected to be able to increase Return on Assets (ROA) and can also have an impact on improving a company's financial performance.

Pramudito's research (2014) states that OPERATIONAL EFFICIENCY has a significant effect on ROA. While Lemiyana and Litriani (2016) in their research explained that OPERATIONAL
EFFICIENCY had a significant negative effect on ROA.

The next factor influencing profitability in Islamic banking is third parties. Third-party funds represent deposits obtained from customers through demand deposits, savings, and deposits. In a theory, it is mentioned that third-party funds are the backbone of bank operations. These funds will be channeled by banks in the form of financing, both financing with profit-sharing agreements (mudharabah and musyarakah), buying and selling (mudharabah) or other complementary contracts such financing generates revenue sharing for 
customers and also for banks which will affect the size of profitability bank.

Figure 2. Comparison of Conventional Banks and Sharia Banks Third Party Funds

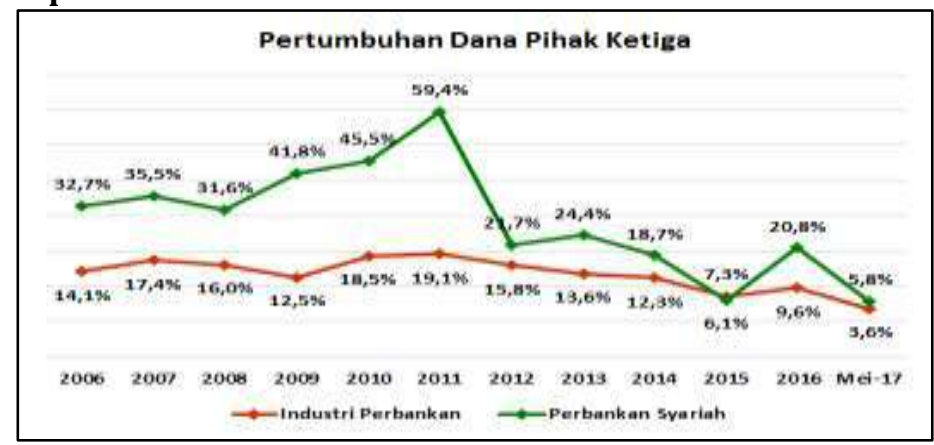

Source: Deposit Insurance Agency

Figure 2 . explained the growth of third party funds in the sharia banking business in the last 5 years tended to decline, except in 2016 which was helped by the conversion of the Aceh Syariah bank. At present there are 13 Sharia Commercial Banks and 21 Sharia Business Units. The number of Sharia Commercial Banks can increase with the conversion plan of several Sharia Business Units. Up to 2017, year to date sharia banking growth was recorded higher than the growth of the banking industry in general.

Anggreni (2014) from her research results explained that third-party funds have a positive effect and are the most influential variable on profitability, it is expected that banks in Indonesia encourage customers to increase their savings in banks by increasing the service of deposit products. Whereas Sukma (2013) in his research explained that thirdparty funds had no effect on profitability in banking companies. The regression coefficient is a negative sign which means the opposite of what was hypothesized. This shows that the greater the third party funds owned by a bank, it does not necessarily reflect the large profits to be obtained by the bank.

Another factor affecting profitability in Islamic banking is Non-Performing Finance. NonPerforming Finance is a tool to measure the ability of bank management in overcoming Financing / Nonperforming loans (Bad Credit) provided by banks to customers. K Asmir (2010) explains that the Credit Risk Ratio is a ratio used to measure the risk of loans extended by comparing bad loans with the number of loans extended. The size of the NPF will affect profitability, because this may reduce the level of profitability in the current year.

In the past 5 years, problematic financing has become a major problem in Islamic banking. Even so, the NPF of Islamic banks has tended to be according since 2012. The high NPF (4.4\%: may 2017) of Islamic banking affected earnings which dropped dramatically in 2014. KPPM of Islamic banking was at the level of $16.9 \%$ but was still lower than the conventional banking capital ratio which reached $22,9 \%$.

\section{Figure 3. Comparison of Non-Performing Finance Conventional Banks and Sharia Banks}

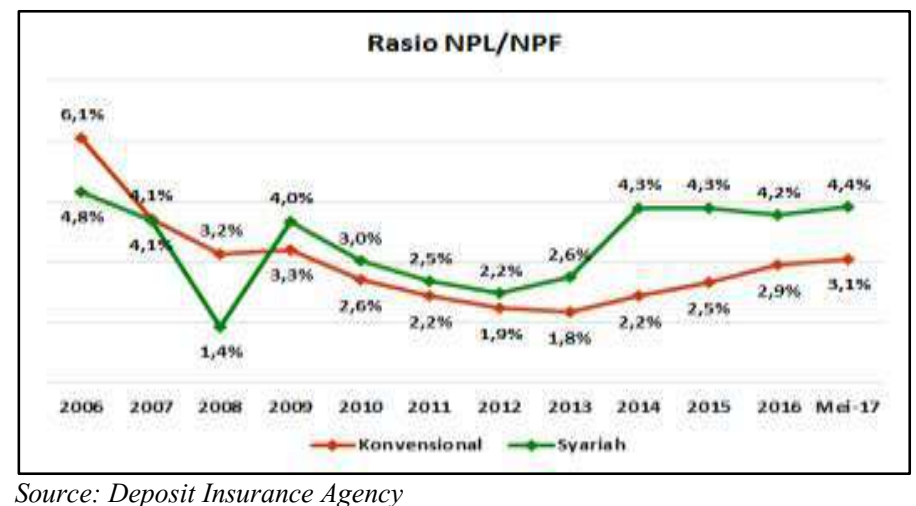

Rahman Research (2012) partially, the sale and purchase financing and NPF ratio have a significant positive effect on profitability which is proxied through Return on assets (ROA) at Islamic commercial banks in Indonesia. Whereas Irmawati (2014) in her research showed that Non-Performing
Finance had no significant effect on profitability (ROA).

This development proves that conceptually, Islamic banking is by the demands of the times to be an alternative banking system by the nature of human life. However, the perfection of the concept based on this regional concept must continue to be 
improved to be able to meet the demands of the evolving era, especially the demands of real business life. Based on the description above background, the writer interested in research with the title "The Effect of Operational Efficiency, Third Party Funds, and Non-Performing Finance $t$ shaddap Profitability p no Islamic Banking di Indonesia".

\section{REVIEW OF AN LITERATURE, FRAMEWORK THINKING, AND HYPOTHESES}

\section{Agency Theory}

Agency theory describes the relationship between shareholders as shareholders and management as agents. Management is a party contracted by shareholders to work in the interests of shareholders. Because they are chosen, the management must account for all its work to shareholders.

Jensen and Meckling (1976) describe agency relationships as "agency relationships as contracts where one or more people (actors) involve other people (agents) to perform some services on their behalf that involve delegating some decision making authority to the agent".

In agency theory, agency relationships arise when one or more people employ another person to provide services and then delegate decision making authority to the agent. The goals of agency theory are:

To improve the ability of individuals (both principals and agents) in evaluating the environment in which decisions must be taken. To evaluate the results of decisions that have been taken to facilitate the allocation of results between the principal and agent by the employment contract.

In connection with this research, investors, fund owners, and shareholders and the government play the role of the party that gives authority (principal), while the bank is the party that receives the authority (agent). The agency relationship at a bank is more complex than that of a non-bank company. These relationships include:

a. Agent-Principal Relationship. Banks tend to obtain large profits with costs borne by the principal. This behavior is often referred to as rational limitations and not all bear the risk (Taswan, 2010). The determination of the bank's management structure, in addition to being appointed by the shareholders, is also under the control of the monetary authority (Bank Indonesia) who will conduct a fit and proper test of the bank's management candidates.

b. Agent Relations - Creditors / Debtors. Control in banking does not only involve the principal, but also the creditor/debtor, which is called market discipline. Using debt or public funds can create agency problems when managers decide to make high-risk investments.

c. Agent-Regulator Relations. Bank agency relationships become more complex because of the role of Bank Indonesia. Banks operate under regulations that are substantially different from non-bank companies and this can affect the nature and effectiveness of control mechanisms (Taswan, 2010). Managers are more likely to maximize utility rather than profit because of the presence of regulators, whose existence influences every decision taken by bank management.

In the banking sector, the application of agency theory is unique because this sector is different from other industries. One of them is very strict regulation, which results in the application of agency theory in banking accounting to be different from accounting for non-banking companies. With this regulation, there are other parties involved in the agency relationship, namely the regulator, in this case, the government through Bank Indonesia (BI) which acts as the principal and banks in Indonesia as their agents. BI must oversee banking activities and performance in Indonesia.

\section{Operating Costs to Operating Income}

Biriyani (2009) explains Operating Costs to Operating Income is a group of ratios that measures the efficiency and effectiveness of a company's operations by comparing one to another. The various income and expenditure figures from the income statement against the numbers on the balance sheet. The operating cost ratio is a comparison between operating costs and operating income.

The ratio of operational costs is used to measure the level of efficiency and the ability of banks to conduct operations. The lower the Operating Costs to Operating Income means the more efficient the bank is in controlling operational costs, the more efficient the cost the bank will get

Operating Costs to Operating Income is a bank effort to minimize operational risk, which is uncertainty regarding bank business activities. Operational risk comes from operational losses if there is a decrease in profits which is influenced by the structure of the bank's operational costs, and the possibility of failure of the services and products offered.

\section{Third-Party Funds}

Banks are community services and a medium for public financial intermediaries. Therefore, banks must always be in the midst of the community so that excess cash flow from the community can be accommodated and distributed to disadvantaged communities. Public trust in the existence of banks and public confidence that banks will carry out their financial problems as well as possible is a condition that is expected by all banks. According to Law No. 21 of 2008 concerning Islamic banking (article 1) states that, "Deposits are funds trusted by the Customer to the Sharia Bank and/or Sharia Business Units based on a Wadi'ah Agreement or other Contracts that do not conflict with Islamic principles in the form of Demand Deposits, Savings, or other forms which is likened to it ". Community funds held in banks are the largest and most reliable source of 
bank funds, consisting of 3 types, namely: in the form of demand deposits, deposits and savings.

$$
\begin{aligned}
\text { Third-Party Funds }=\underset{\text { Deposit }}{\text { Current Account }+ \text { Savings }+} &
\end{aligned}
$$

a. Demand Deposit. Demand deposits are deposits based on wadi'ah contracts or other contracts that do not conflict with the principles of Sharia which can be withdrawn at any time by using checks, crossed checks, other means of payment orders, or with book transfer orders.

b. Time Deposits. Deposits are investment funds based on mudharabah contracts or other contracts that do not conflict with sharia principles, which can only be withdrawn at a certain time based on a contract between the Depository Customer and the Sharia Bank and Sharia Business Units.

c. Savings. Is a deposit based on the Wadi'ah contract or investment fund based on mudharabah card or another contract that is not in conflict with the Sharia principles, the withdrawal can only be carried out according to certain agreed terms and conditions, but cannot be withdrawn by check, giro, and other similar instruments with that.

\section{Non-Performing Financing (NPF)}

Non Performing Financing is a problem financing that is experienced by banks (bad credit), this problem financing will affect the performance of the bank as a financial institution and will have an impact on the profits to be obtained by the bank. The least encouraging development of financing provision for banks is when the financing provided turns out to be problematic. This is mainly due to the failure of the debtor to fulfill its obligation to pay the installments (installments) of the principal financing along with the profit-sharing agreed by both parties in the financing agreement. The implications for banks as a result of the emergence of problem financing can be as follows:

a. The loss of the opportunity to earn income (income) from credit provided, thereby reducing profitability and adversely affecting bank profitability.

b. The ratio of earning asset quality or better known as BDR (bad debt ratio) is getting bigger which illustrates the worsening situation.

c. Banks must increase the allowance for productive assets reserves which are classified based on existing provisions.

Figure 4.Thought Framework

The Effect of Operational Efficiency, Third Party Funds, and Non Performing Finance on Profitability in Islamic Banking in Indonesia d. Return On Assets (ROA) has decreased.

e. As a result of complications in items 2, 3, and 4 above, the value of the bank soundness has decreased based on calculations according to the CAMEL method.

\section{Return On Assets (ROA)}

The justification for using profitability is that this ratio can provide a measure of a company management's effectiveness, as well as in measuring the level of a company's profitability. Moreover, ROA is the ratio that assesses a company's ability to seek profits (CM Doktoralina, D Anggraini, SM Safira., 2018). Return On Assets (ROA) measures the rate of return on assets used in generating profits, or in other words ROA is an indicator of a business unit to obtain a return on several assets owned by the business unit. ROA can be obtained by calculating the ratio between profits after tax divided by total assets. ROA is a ratio that is used to measure the ability of banks to obtain profits (profits) as a whole. The greater the value of this ratio indicates the level of profitability of the bank's business is getting better or healthier, stable or healthy ROA ratio reflects the stable amount of capital and bank profits. Stable banking conditions will increase the ability of banks to extend credit (Meydianawati, 2007).

The profitability ratio consists of two types of ratios that show profitability in relation to sales and ratios that show profitability in relation to investment. Together, this ratio will show the overall operational effectiveness of the company (Van Horne and Wachowicz, 2013 in Indiriawati,2019)

Return on Assets (ROA) is one of the profitability ratios. In the analysis of financial statements, this ratio is most often highlighted, because it can show the company's success in making a profit. ROA can measure the company's ability to generate profits in the past and then projected in the future. Assets or assets in question are the entire assets of the company, obtained from own capital or from foreign capital that has been converted by the company into company assets that are used for company survival (Tanjung, 2019)

\section{Thought Framework}

Based on the periodization chosen in this study and the previous description, the theoretical framework of this research is described as follows:

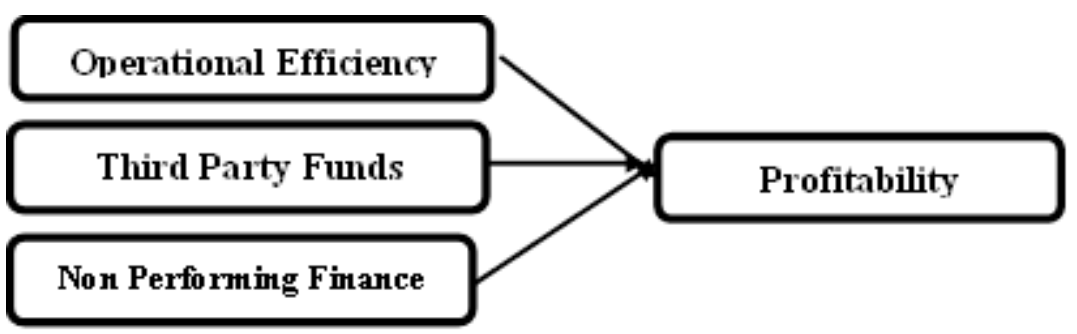




\section{Research Hypothesis Effect of Operational Efficiency on Profitability}

Operating costs to Operating Income which is the financial ratio used to measure the level of efficiency and effectiveness of banks in carrying out their operations. This Operating costs to Operating Income ratio measures the ability of operational opinion in covering operational costs, from the value of this Operating costs to Operating Income can be seen as the condition of the performance of the bank concerned.

If the Operating costs to Operating Income ratio at a bank is high, it means that the costs incurred by the bank for operations are greater than the operating income coming into the bank. If the bank's operating income is small, the profitability level of the bank becomes low, this shows the opposite relationship between Operating costs to Operating Income and the profitability level of a bank that is in line with Wibowo research (2013) which found that Operating costs to Operating Income has a negative effect on the profitability of Islamic banks.

Based on the description above, the hypotheses that can be formulated are:

$\mathrm{H} 1$ : Operating costs to Operating Income harms profitability

\section{Effects of Third Party Funds on Profitability}

The more funds owned by banks, the greater the chances of banks to carry out their functions. The importance of sources of funds from the wider community, due to sources of broader public funds is the most important source of funds for banks (Kasmir, 2005).

Table 2. List of Islamic Banks in Indonesia for the period 2012-2016

\begin{tabular}{l|l} 
No & \multicolumn{1}{|c}{ Sharia Bank Name } \\
\hline 1 & PT. Bank Muamalat Indonesia \\
\hline 2 & PT. Bank Syariah Mandiri \\
\hline 3 & PT. Bank Syariah Mega Indonesia \\
\hline 4 & PT. Bank BNI Syariah \\
\hline 5 & PT. Bank BRI Syariah \\
\hline 6 & PT. Bank Bukopin Syariah \\
\hline 7 & PT. Bank BCA Syariah \\
\hline 8 & PT. Bank Victor Syariah \\
\hline 9 & PT. Bank Panin Syariah \\
\hline 10 & PT. Bank Maybank Syariah Indonesia \\
\hline 11 & PT. Bank Jabar Banten Syariah \\
Source: BI Data (Bank Indonesia)
\end{tabular}

Two Sharia Commercial Banks that were not included were the Aceh Syariah Bank and the Sharia State Pension Savings Bank.

This data processing method is quantitative by using panel data regression data processing. Panel
According to Sinungan (1997) namely the increasing market share of third-party funds, the more, the increase in credit provided. This theory is supported by research conducted by Sukma (2013) that third-party funds have a positive influence on profitability which means when third party funds have increased, then ROA will also increase.

Based on the description above, the hypotheses that can be formulated are:

H2: Third-Party Funds have a positive effect on profitability.

\section{Effect of Non-Performing Finance (NPF) on Profitability}

Ismail (2010) what is meant by Non-Performing Finance is financing channeled by banks, and customers cannot make payments by agreements that have been signed by banks and customers. If the NPF shows a low value, it is expected that income will increase, but conversely, if the NPF value is high, the income will decrease so that the profits obtained will decrease. The direction of the relationship that arises between the NPF and ROA is negative because if the NPF is high, it will result in a decrease in income and will affect the decline in ROA obtained by Islamic banks (Riyadi, 2014).

Based on the description above, the hypotheses that can be formulated are:

\section{H3: Non-Performing Finance harms profitability}

\section{RESEARCH DESIGN AND METHOD}

Based on data obtained through the website www.bi.go.id there were 11 Sharia banks registered at Bank Indonesia during the study period from 2012 to 2016

data is a combination of time series data and crosssection data. The regression equation proposed in this study is as follows:

$$
\mathrm{ROA}=\alpha+\beta 1 \mathrm{EF}+\beta 2 \mathrm{DPK}+\beta 3 \mathrm{NPF}+\mathrm{e}
$$


Information:

$\begin{array}{ll}\text { ROA } & : \text { Return On Assets } \\ \alpha & : \text { Constanta } \\ \beta 1, \beta 2, \beta 3 & : \text { Regression coefficients on each } \\ \text { variable } & \\ \varepsilon & : \text { error } \\ \text { EF } & : \text { Operational Efficiency } \\ \text { DPK } & : \text { Third-Party Funds } \\ \text { NPF } & : \text { Non-Performing Finance }\end{array}$

The research data were analyzed and tested with several statistical tests. The test consists of descriptive statistics, classic assumption tests, and regression analysis for hypothesis testing.

\section{RESULTS AND DISCUSSION \\ Descriptive Statistics Test Results}

Descriptive Statistics provides an overview of data that can be seen from the average value (mean), the size of the spread of data from the average (standard deviation), the maximum and minimum values. The following are the results of the descriptive statistics of the study which can be seen in table 3 :

Table 3. Descriptive Statistics

\begin{tabular}{|c|c|c|c|c|c|}
\hline & $\mathbf{N}$ & Minimum & Maximum & Mean & Std. Deviation \\
\hline BOPO & 55 & ,4760 & 1,9260 & 946744 & ,2226867 \\
\hline DPK & 55 & 4293720 & $\begin{array}{c}69950000 \\
0\end{array}$ & 144664263,27 & $\begin{array}{c}188244023,0 \\
97\end{array}$ \\
\hline NPF & 55 & 1 & 2610 & 401,76 & 412,470 \\
\hline ROA & 55 & -2013 & 448 & 17,15 & 357,919 \\
\hline $\begin{array}{l}\text { Valid N } \\
\text { (listwise) }\end{array}$ & 55 & & & & \\
\hline
\end{tabular}

From table 3 above, it can be seen that the value of $\mathrm{N}=55$ represents the number of sample data (annual data for 5 years from 11 Sharia Commercial Banks). The deposit data used in this study is the ROA collected by Sharia Commercial Banks in the 2012-2016 period recorded in Sharia Commercial Bank statistics published on the www.bi.go.id and www.ojk.co.id sites. Then from the table shows that the dependent variable Return on Asset has a minimum value of $-20,13 \%$ in Maybank Syariah Bank in 2015 because the Operational Efficiency in Maybank in 2015 is greater than in other years, while for a maximum value of $4,48 \%$ at Panin Syariah Bank in 2012 because the operational efficiency at Panin Bank in 2012 was smaller than in other years . The average value of Return On Assets is 17.15\% and the size of the data distribution of the average (standard deviation) of 357,919

The independent variable Operational Cost and Operating Income has a minimum value of $47.6 \%$ at Bank Panin Syariah in 2012 because ROA at Panin Bank in 2012 is greater than other years while for a maximum value of $192.6 \%$ at Bank Maybank Syariah in 2014 because the amount of ROA in BMSI in 2014 was lower than in other years. The average value of OPERATIONAL EFFICIENCY is $94.6744 \%$ and the size of the data distribution of the average (standard deviation) is 22.26867.

The independent variable Third Party Fund has a minimum value of 429372000000,00 at the Bank Maybank Syariah in 2016 because of its NPF has decreased in the last 4 years, while the maximum value amounted to $69,950,000,000,000,00$ at the Bank Mandiri Syariah year 2016. The mean size of the Company amounted to $144 \quad .664 .263,27$ and measurement data from the dissemination of the mean (standard deviation) of 188. 244.023 .097

The independent variable Non-Performing Finance (NPF) has a minimum value of $0.1 \%$ at
Bank BCA Syariah in 2012 to 2014, while for a maximum value of $26.10 \%$ at Bank BNI Syariah in 2013 because its ROA decreased compared to 2012. The average value of NPF at 401.76 and the size of the deployment of the data from the mean (standard deviation) of 412.470 .

\section{Classical Assumption Test}

The classic assumption test is carried out to determine the condition of existing data to determine the most appropriate analysis model to use. The classic assumption test is carried out to determine the condition of existing data to determine the most appropriate analytical model to use. The classic essay test in the study consisted of the normal P Plot test to test data normality statistically, the Multicollinearity Test using Variance Inflation Factors (VIF), Autocorrelation Test using Durbin Watson statistics, and the heteroscedasticity test by looking at the results of Spearman data rho.

In this study, the data that has been obtained is to determine the extent of the influence of the variables between operational efficiency, Third Party Funds, and Non-Performing Finance on Profitability.

\section{Normality Test}

A normality test is done to see whether the independent and dependent variables have a normal distribution. The purpose of normal distribution data is that the data will follow the direction of the diagonal line and spread around the diagonal line. The normality test is intended to test whether the standardized residual values in the regression model are normally distributed or not. The residual value is said to have normal distribution if the standardized residual value is mostly close to the average value. In this study, researchers used the normality test with graph analysis and the Kolmogorov-Smirnov test. Following are the results of this test : 
Tabel 4.One-Sample Kolmogorov-Smirnov Test

\begin{tabular}{|lc|c|}
\hline & & Unstandardized Residual \\
\hline $\mathrm{N}$ & & 55 \\
Normal & Mean & $0 \mathrm{E}-7$ \\
Parameter & Std. Deviation & 148,15485671 \\
sa,b & Absolute &, 227 \\
Most & Positive &, 181 \\
Extreme &,- 227 \\
Difference & Negative & 1,683 \\
s &, 070 \\
\multicolumn{2}{|c|}{ Kolmogorov-Smirnov Z } \\
\multicolumn{2}{|c|}{ Asymp. Sig. (2-tailed) }
\end{tabular}

a. Test distribution is Normal.

b. Calculated from data

Based on the sample above, the KolmogorovSmirnov KS test is Asymp.sig. (2-tailed) $>0.05$, then the regression model meets the assumption of normality or Ho is accepted.

\section{Multicollinearity Test}

Namely, the emergence of opportunities among several independent variables to correlate with each other, in practice multicollinearity cannot be avoided. Measuring multicollinearity can be seen from the value of Tolerance and Variance Inflation Factor (VIF). Tolerance measures the variability of other independent variables. So a low tolerance value equals a high VIF value because of VIF $=1 /$ tolerance. The cut-off value commonly used to indicate multicollinearity is a tolerance value $<0.10$ or equal to $\mathrm{VIF}>10$.

The tolerance value of the independent variable is Operational Efficiency $=0.991$, Third Party Fund $=0.921$, and NPF $=0.926$. while the VIF value of the independent variable Operational Efficiency = 1,009 , Third Party Fund $=1,086$, and NPF $=1,080$. It can be concluded that the regression model stated there are no symptoms of multicollinearity because of the value of toll erance $>0.1$ and VIF value $<10$.

\section{Heteroscedasticity Test Results}

Heteroscedasticity is a condition where all residuals or errors have variants that are not constant or changeable. To find out whether a data is heteroscedasticity or not, it needs testing. Based on the result, it can be concluded that the correlation value of the three independent variables with Unstandardized Residual has a significant value of more than 0.05 . Because it is significantly more than 0.05 , it can be concluded that there was no heteroscedasticity problem in the regression model and Ho was accepted.

\section{Autocorrelation Test}

The autocorrelation test aims to find out whether there is a correlation between members of a series of observational data broken down according to time (time-series) or space (cross-section). One of the causes of the emergence of the Autocorrelation problem is the presence of inertia, which means that it will most likely contain interdependence on the observation data of the previous and present periods. One of the measurements in determining the presence or absence of $\mathrm{Au}$ autocorrelation problems is the Durbin-Watson (DW) test. Based on result the value of Durbin Watson (DW) of 2,023. So it can be concluded that in this regression model there is no autocorrelation, positive/negative because the code $\mathrm{du}<\mathrm{d}<4$ - $\mathrm{dl}$ produces $(1.6815<2.023<4-1.6815)$ $(2.023<2.3185)$ which means it does not reject.

\section{Multiple Regression Test Results}

In this study, the analysis technique used is multiple regression analytical methods. Multiple linear regression analysis is a regression in which the dependent variable $(\mathrm{Y})$ is connected by more than one independent variable. (X 1, X 2, X 3 .... X n ). The use of this analysis method to analyze the effect of Operational Efficiency, Third Party Fund, NonPerforming Finance (NPF) on Return On Assets (ROA) with the basic model can be written as follows:

The Regression Equation is as follows:

$$
\begin{gathered}
\mathrm{ROA}=\alpha-\beta 1 \mathrm{BOPO}+\beta 2 \mathrm{DPK}+\beta 3 \mathrm{NPF}+\mathrm{e} \\
\mathrm{ROA}=1366,244-1448,155 \mathrm{BOPO}+6,029 \mathrm{E}-008
\end{gathered}
$$$$
\mathrm{DPK}+0.033 \mathrm{NPF}
$$

If everything independent variable is considered constant or zero value, it means that the independent variable decreases, then the value of Return On Assets (ROA) is 1366,244 one-unit. The Operational Efficiency coefficient value is -1448.155 percent which means that every increase in Operational Efficiency by 1 percent will decrease ROA by 1448.155 one-unit.Third-Party Funds regression coefficient value of $6.029 \mathrm{E}-008$ percent which means that each increase in Third Party Funds by 1 percent will increase ROA by $6.029 \mathrm{E}-008$ one-unit. Non-Performing Finance (NPF) regression coefficient value of 0.033 percent which means that every 1 percent increase in NPF will increase ROA by 0.033 one-unit.

\section{Test The coefficient of determination (R')}

The coefficient of determination or $\mathrm{R}^{2}$ is the contribution of independent variables on the dependent variable. The higher the coefficient of 
determination, the higher the ability of the independent variable in explaining the variation of changes in the dependent variable. The coefficient of determination has a weakness, namely the bias towards the number of independent variables included in the regression model where each addition of one independent variable and the number of observations in the model will increase the RSquare value even though the entered variable does not have a significant effect on the dependent variable. To reduce these weaknesses the adjusted determination coefficient is used, Adjusted R Square

The adjusted determination coefficient means that the coefficient has been corrected by entering the number of variables and the sample size used. By using the adjusted determination coefficient, the adjusted determination coefficient value can go up or down by the addition of new variables in the model.

The amount of Adjusted R Square is 0.814 or $81.4 \%$. It can be concluded that the influence of operational efficiency, Third-Party Funds, and NPF on ROA in Islamic Commercial Banks is $81.4 \%$, while the remaining $18.6 \%(100 \%-81.4 \%)$ is influenced by other variables not included in the study this is. The correlation coefficient number (R) shows a value of 0.908 which indicates that the relationship between the independent variable and the dependent variable is strong because it has a value of more than $0.5(\mathrm{R}>0.5)$ or $0.908>0.5$.

Simultaneous Significance Test (Test F)

F count test is used to simultaneously test the effect of independent variables on the dependent variable or to test the accuracy of the model (goodness of fit). If the independent variables have a simultaneous influence (together) on the dependent variable then the regression equation model is included in the fit or fit criteria. Conversely, if there are no simultaneous influences in the category of unsuitability or not fit.

The method of testing in this F test, namely by using a table called the ANOVA (Analysis of Variance) Table by looking at the significance value (Sig $<0.05$ or $5 \%$ ). If the significance value $>0.05$ then $\mathrm{H} 1$ is rejected, conversely if the significance value $<0.05$ then $\mathrm{H} 1$ is accepted. $\mathrm{N}$ use values of $\mathrm{F}$ obtained 79.581 with a significance level of 0.000 , due to the significance level of less than 0.05 then $\mathrm{HO}$ is rejected or accepted H1. It can be concluded that operational efficiency, Third-Party Funds, and NPF together have a significant influence on Return On Assets (ROA).

Partial Significance Test (T-Test)

After conducting the overall regression coefficient test, the next step is to calculate the regression coefficient individually or the t-test. The T-test is used to determine whether there is an influence of each independent variable individually (partial) on the dependent variable tested at the level of significance (Sig. 0.05 or 5\%), then the independent variable influences the dependent variable.

a. Operational efficiency has a significant effect on ROA.Based on statistics show significant results in a smaller value of $\alpha(0.000<0.05)$. It can be concluded that the operational efficiency variable influences Return on Assets (ROA).

b. Third-Party Funds has no significant effect on ROA. Based on statistics show significant results in a larger value of $\alpha(0,607>0.05)$. Then it can be concluded that the Third-Party Funds variable does not affect Return On Assets (ROA).

c. NPF does not affect ROA.Based on statistics show results are not significant at a larger value of $\alpha(0.538>0.05)$. It can be concluded that the NPF variable does not affect the Return On Assets (ROA).

\section{Discussion of Regression Results}

\section{Operational Efficiency effect on}

\section{Return On Assets}

The calculation results of the operational efficiency variables statistically show significant results at values smaller than $\alpha$ $(0,000<0.05)$. So $t$ count $<\mathrm{t}$ table $(-15.265<$ $0.05)$. Then $\mathrm{H} 1$ is accepted so that it can be concluded that the operational efficiency variable has a significant negative effect on Return on Assets. Based on previous research by Wibowo (2013) " Effect of Interest Rates, Inflation, CAR, operational efficiency, NPF on ROA" which shows operational efficiency has a significant effect on ROA in a negative direction.

If the operational efficiency ratio at a bank is high, it means that the costs incurred by the bank for operations are greater than the operating income coming into the bank. If the bank's operating income is small, the profitability level (ROA) of the bank becomes low, this shows the opposite relationship between operational efficiency and the profitability level (ROA) of a bank that is in line with Wibowo's research (2013) which found that operational efficiency has a negative effect on the profitability of Islamic banks.

\section{DPK does not affect Return On Assets}

Calculation results variables statistically show insignificant results at values greater than $\alpha(0,607>0.05)$. So that $\mathrm{t}$ count $>\mathrm{t}$ table $(0.518>0.05)$. Then $\mathrm{H} 1$ is rejected so that it can be concluded that the Third-Party Funds variable has no significant effect on Return on Assets. Based on previous research Sukma (2013) " The Effect of Third Party Funds, Capital Adequacy and Credit Risk on Profitability ". The results of the analysis conducted, third-party funds do not affect the profitability of banks. This means the higher Third-Party Funds collected by the BUS will not 
increase ROA. This might be influenced by the NPF value which is increasing every month.

While Anggreni (2014) "The Effect of Third Party Funds, Capital Adequacy, Credit Risk and Credit Interest Rates on Profitability (ROA)". From the results of these studies indicate a variable Third-Party Funds has a positive effect on profitability. Third-Party Funds increases, so banks have the opportunity to provide greater opportunities to obtain higher income. It can be said Third-Party Funds has a positive relationship with profitability calculated by the ROA ratio.

3. NPF does not affect the return on assets

The calculation result of the variables NPF statistically the results are not significant at a larger value of $\alpha(0.538>0.05)$. So that $t$ count $>$ $\mathrm{t}$ table $(0.621>0.05)$. Then $\mathrm{H} 1$ is rejected so it can be concluded that the NPF variable has no significant effect on Return On Assets (ROA).Based on previous research Irmawati (2014) " The Influence of FDR, Sale and Purchase Financing, Profit Sharing Financing, Leasing and NPF Financing on Profitability" The results showed that Non-Performing Finance (NPF) had no significant effect on profitability (ROA).

That the greater the NPF has an impact on decreasing profitability (ROA). Problematic financing is related to the possibility that at the maturity of the debtor the fund fails to fulfill its obligations to the bank so that it can affect the performance of the bank causing many disbursed financing to yield no results and result in greater reserves resulting in ultimately bank ROA income being reduced. Financing losses result in decreased profits which have an impact on health.

\section{CONCLUSIONS AND SUGGESTIONS}

\section{Conclusions}

1. Operational Efficiency has a significant negative effect on profitability

2. Third-Party Funds do not affect profitability

3. Non-Performing Finance does not affect profitability

\section{Suggestions}

Based on the conclusions of the results of the research that has been described, the authors try to put forward some suggestions that need to get emphasis in the future including:

1. Sharia Bank. With the findings that Operational Efficiency, Third Party Funds and NonPerforming Finance together have a significant influence on Return On Assets with different levels of contributions shows that Islamic banking performance can be measured from these variables, therefore for practitioners it is expected able to improve banking performance positively with the aim that if it is calculated on a national scale, the performance of sharia banking as a whole will also be positive with the above measures. The results of this study can be useful for evaluating the development of the sharia banking system as well as starting material for the study in determining the method of sharia monetary policy.

2. For Customers. With the findings that Operational Efficiency, Third Party Funds, and Non-Performing Finance together have a significant effect on Return On Assets with different levels of contributions. The Return On Asset variable is a measure of a customer's interest in saving his funds. However, in choosing the type of banking, of course, many factors are considered. In sharia banking, for example, customers see the magnitude of Operational Expenses and Operational Income of the Islamic bank. Besides, customers are also still affected by the amount of profit-sharing provided by conventional banks as a trigger for them to keep their money in the bank. This research is expected to be information that will add insight and knowledge to bank customers. So that it can be used as a guide as a decision in investing that can provide a level of profit by investor expectations.

3. For Academics. This research will add to the literature in the field of banking management and can be used as reading material to add insight knowledge, especially about Return On Assets. For further research, it is better to increase the number of variables from internal and external factors of the bank, for example: Capital Adequacy Ratio, Financing to Deposit Ratio, Return On Equity, GDP, unemployment rate, BI rate, exchange rate, bank size, and others.

\section{REFERENCES}

1. Adyani, Layla Rahma. (2011). Analysis of Factors Affecting Profitability (ROA). Diponegoro University's Faculty of Economics.

2. Anggreni, Made Ria, \& Suardhika, I Made Sadha. (2014). Effects of Third Party Funds, Capital Adequacy, Credit Risk and Credit Interest Rates on Profitability. E-journal of Udayana University Accounting.

3. Ariyani, Desi. (2009). Analysis of the effect of CAR, FDR, BOPO, and NPF on profitability at PT Bank Muamalat Indonesia Tbk (January: 2005- April: 2008)

4. Cashmere. (2010). Banks and Other Financial Institutions. Revised Edition. Jakarta: PT. Raja Grafindo Persada.

5. CM Doktoralina, D Anggraini, SM Safira. 2018. The Importance of Sustainability Reports In Non-Financial Companies. Jurnal Akuntansi/Volume XXII, No. 03, September 2018: 368-384

6. Ghozali, Imam. (2016). Multivariate Analysis Application with the IBM SPSS 23 Program. 7. Semarang edition. Diponegoro University Publisher Agency. 
7. Ichsan, Randhy. (2013). Agency Theory. Retrieved from http://bungrandhy.wordpress.com/2013/01/12/te ori-keagenan-agency-theory /amp/

8. Indiriawati, Fitri, The Incremental Value of Islamic Social Reporting: Evidence from Companies Listed in Jakarta Islamic Index (August 8, 2019). Journal of Economics and Business, Vol.2 No.3 (2019). Available

SSRN: $\underline{\text { https: } / / \text { ssrn.com/abstract }=3434488}$

9. Irmawati, Erlyta Dhessy. (2014). The Influence of FDR, Sale and Purchase Financing, Profit Sharing Financing, Leasing Financing, and Non-Performing Finance on Profitability. Diponegoro University Thesis.

10. Ishmael. (2010). Banking Management: From Theory to Application. First edition, 1st edition. Jakarta: Kencana.

11. Lemiyana \& Litriyani, Erdah. (2016). Effect of NPF, FDR, BOPO on Return On Assets (ROA) at Islamic Commercial Banks. Economic Vol.2.

12. Mortono (2002). Banks and Other Financial Institutions. Yogyakarta: Ekonisia.

13. Rahman, Aulia Fuad, \& Rochmanika, Ridha. (2012). Effect of Sales and Purchase Financing, Profit Sharing Financing, and Non-Performing Financing Ratio to Profitability of Islamic Banks in Indonesia. Faculty of Economics and Business Universitas Brawijaya

14. Rahmat, Muhammad. (2012). Effect of CAR, FDR, and NPF on Profitability at Bank Syariah Mandiri. Faculty of Economics and Business Hasanuddin University Makassar.

15. Riyadi, Slamet, and Agung Yulianto. (2014). "The Effect of Profit-Sharing Financing, Sale and Purchase Financing, Financing to Deposit Ratio (FDR) and Non-Performing Financing (NPF) on the Profitability of Sharia Commercial Banks in Indonesia. Accounting Analysis Journal 3 (4).

16. Septiawan, Nova Herga. (2009). Effects of Third Party Funds and Non-Performing Finance on Profitability in Islamic Banking in Indonesia. Jakarta: Thesis of Mercu Buana University.

17. Sukma, Yoli Laras. (2013). The Influence of Third Party Funds, Capital Adequacy and Credit Risk on Profitability. Accounting Study Program, Faculty of Economics, University of Padang.

18. Tanjung, Putri Renalita Sutra. 2019. Analysis of The Effect Of Economic Value Added And Other Fundamental Factors of Share Returns. EPRA International Journal of Multidisciplinary Research (IJMR) Volume: 5 | Issue: 9 p 141-149. September 2019. ISSN (Online): 2455-366

19. Wati, Ishmah. (2012). Analysis of the Effect of Operational Efficiency on Profitability Performance in the Sharia Banking Sector. Faculty of Economics, University of Indonesia Thesis Depok program.

20. Wibowo, Edi Satriyo. (2013). Analysis of the Effect of Interest Rates, Inflation, CAR, OPERATIONAL EFFICIENCY, NPF, on the Profitability of Islamic
Banks. Diponegoro University's Faculty of Economics and Business.

21. Zainul Arifin. (2002). Fundamentals of Sharia Bank Management . Jakarta: Alvabet. 